\title{
RULE OF LAW VERSUS SOFT RULE OF LAW
}

\author{
RUBÉN MÉNDEZ REÁTEGUI
}

OSCAR SUMAR ALBUJAR 


\section{SUMMARY}

INTRODUCTION. II. THE RULE OF LAW: A CONCISE REVISION. III. RULE OF LAW AND SOFT RULE OF LAW. IV. HUMAN RIGHTS AND THE RULE OF LAW. V. RULE OF LAW AND DEMOCRACY. VI. RULE OF LAW AND CONSOLIDATED DEMOCRACY. VI.1. Rule of Law and State Reform. VII. SOFT RULE OF LAW IN ECUADOR AND PERU. VIII. CONCLUSION. REFERENCES. 
Fecha recepción: 25/03/2020

Fecha aceptación: 06/07/2020

\title{
RULE OF LAW VERSUS SOFT RULE OF LAW
}

\author{
RUBÉN MÉNDEZ REÁTEGUI \\ Full-tenured professor at Pontifical Catholic University of Ecuador - PUCE \\ Visiting Professor of Law at University of Technology of Perú \\ OSCAR SUMAR ALBUJAR ${ }^{1}$ \\ Dean of the Law School at Universidad Científica del Sur
}

\section{INTRODUCTION}

Moving to real development in Ecuador and Peru, it is necessary to promote and protect the full enjoyment of rights referred to in The Universal Declaration of Human Rights ${ }^{2}$ and other international instruments. One of the most important and current concerns is about serious problems faced by the lack of respect for some fundamental rights such as the right to property, hence the relevance of some reflections on the importance of and the close relationship between the Rule of Law (when the law limits the power) versus the Soft Rule of $L a w^{3}$ (when the law reflects and protects

1 Rubén Méndez Reátegui, Full-tenured Professor of Law and Economic and Group of Research on Economic Law (GIDE) coordinator at Pontifical Catholic University of Ecuador (PUCE), visiting professor at the Faculty of Law and Human Science of the Universidad Tecnológica del Perú (UTP) and researcher at USAL and visiting international professor at U. Externado de Colombia. Email: rcmendez@ puce.edu.ec (main author). In the case of Dr. Mendez, it is stated that this article constitutes an original contribution within Project IV (Regulatory Improvement) of the Research Group on Economic Law (GIDE) of the Pontifical Catholic University of Ecuador (PUCE) and USAL's Faculty of Law.

Oscar Sumar Albujar, Dean of the Law School and Law Professor, Universidad Científica del Sur (Perú). Project IV (Regulatory Improvement) director. Email: osumar@cientifica.edu.pe (corresponding author).

Authors would like to thank Lissangee García Mendoza for her research assistance.

2 The Universal Declaration of Human Rights (UDHR) is a common standard of achievements for all peoples and all nations. It was proclaimed by the United Nations General Assembly in Paris on 10 December 1948 - General Assembly resolution 217 (III)A.

3 Ghersi, E. (2009). «Las Consecuencias Jurídicas del Mercantilismo» (The Juridical Consequences of Mercantilism). Revista El Cato, vol. 9. Consequently, on the one hand, the Rule of Law exists when there is separation of powers, when citizens are equal before the law and where the law limits the power instead of being reflected. On the other hand, there is a Soft Rule of Law, when the law reflects

(C) UNED. Revista de Derecho Político

N. ${ }^{\circ} 109$, septiembre-diciembre 2020, págs. 373-400 
the power of the government rather than limiting it), human rights and democracy. Therefore, this paper will explore the following research questions:

1. Is the current macro legal framework in Peru and Ecuador consistent with what is generally defined as Rule of Law or is it more related to what is known as Soft Rule of Law?

2. To what extend does a theoretical analysis support the prevailing of a Soft Rule of Law in Ecuador and Peru?

This paper has been divided into seven sections. Section one refers to a theoretical revision of the term Rule of Law, section two presents on the concept of soft rule of law, section three focuses on human rights as an essential element of the Rule of Law, section four explores the interaction between democracy and the Rule of Law, section five refers to the challenges faced by the Rule of Law in a consolidated democracy, section six presents, as an example, a brief reflection on the current problems of Peru and Ecuador and finally the paper's conclusions are submitted.

\section{THE RULE OF LAW: A CONCISE REVISION}

The term Rule of Law has been used in legal science and German ${ }^{4}$ politics of the past century to designate a specific relationship between the political form State and the Law, a relationship that goes beyond a limited government that envelops its performance in the guise of legal norms. ${ }^{5}$

and protects the power of the government rather than limiting it. Therefore, the one who receives protection is the political power, not the ordinary citizen, regardless of whether they are rich or poor, and their fundamental rights are at risk.

4 The original conception of the term 'Rule of Law' has its origin in German doctrine (Rechststaat) and is attributed to Robert von Mohl. The term was primarily described in Mohl's book entitled «German Policy Science according to the Principles of the Constitutional State» (Die deutsche Polizeiwissenschaftnach den Grundsätzen des Rechtsstaates). For Mohl, the term refers to a social scenario where the authority (government) enforcing the law also submits to it. Therefore, the government is no longer represented by the people but by the legal rule itself. Then, in a second stage, the Rule of Law involves the scope of judicial review of administrative activity. The third stage began after the First World War. This time the term Rule of Law included democratic legitimacy of government, which also has to be subject to legal rules. For modern legal scholars, the Rule of Law is the political organization of social life guided by the principle of legality and respecting all «fundamental rights». However, following a classic liberal approach, in this paper the final understanding of the term Rule of Law refers to government under the law or the constitutional protection of individual rights. It includes a view of limited and efficient small political administration.

5 German doctrine establishes the state on the administrative law about the subjective public rights on justice administration, Nolte, G. (1994). «General Principles of German and European Administrative Law: A Comparison in Historical Perspective». The Modern Law Review, vol. 57, num. 2, pp. 191-212; SingH, M. P. (1985). German Administrative Law, Berlin, Springer-Verlag Berlin Heidelberg, pp. 1-377. In other words, it subordinates the administrative power to the budget of 
The State apparatus (government and administration) is presented with the face of the power of supremacy that uses state action against citizens. At this point the principle of legality instead of an abstract interpretation of Rule of Law, represents the axis of the new state with separation of powers, above all the subordination to the law of administrative action (in the formal sense: legislative allocation of power, and equipment: eventual internal limiting modes and means of exercise), and a symbol of persecution, subordinate to any other, the general interest, otherwise constitutively prefigured and determined by the law. ${ }^{6}$

Therefore, following the approach formerly described, the Rule of Law appears as the server, strictly controlled by society; it is subject to a closed system of legal rules or simply identified with that system of rules, so it becomes the standard procedure. ${ }^{7}$

It is, consequently, necessary to talk about the theme of the obligation to enforce the laws we refer to as some considerations of historical character on the origin and the supremacy of law and, therefore, whether it is right to use them to govern. Plato stated that the «government of laws» was presented as ideal, in contrast to the «government of men» with its arbitrariness and abuse. Such laws would not be anything other than those dictated by reason. Aristotle, in his work «Politics», spoke of the laws and principles from human reasoning and relates them to the different forms of government defined along the different types of possible Constitutions. ${ }^{8}$ Meanwhile, the philosophers known as stoic explicitly proposed that laws had no other precedent than a contractual arrangement amongst the men who then obey; while the so-called sophists had suggested at the time that all political truth, including of course the laws, emerged from a rhetoric whose ultimate goal was to obtain the citizens' consent. ${ }^{9}$ Despite their differences, they all agreed to hold the Rule of Law against the despotic ideal, e.g. the supremacy of the Rule of Law on the government of men. ${ }^{10}$

According to the scholastic Christian thinking that prevailed during the Middle Ages, any law, natural or human, was an expression of the will of God, and if some

attribution by law, it justifies (through complex theoretical devices) the subsistent rights of citizens before the State and it predisposes judicial means for protection.

6 Esquivel, J. (1972). «Review of Filosofía del Derecho». Crítica: Revista Hispanoamericana De Filosofía, vol. 6 num. 16/17, pp. 142-145; Romero-PÉrez, J. E. (1984). «Principio de legalidad», Revista de Ciencias Jurídicas, num. 51, pp. 126-138.

7 Egaña, J. (2015). «Estado de Derecho». Ediciones Universidad Católica de Chile (eds.). Derecho Constitucional chileno I, Santiago de Chile, Ediciones UC, pp. 291-316. In fact, the Rule of Law, despite all the legality and regulations, remains a state, and always contains other specifically political elements that are more precise items of Rule of Law.

8 De Vergottini, G. (2005). Derecho Constitucional Comparado (Comparative Constitutional Law), Buenos Aires, Editorial Universidad, pp. 1-908.

9 Prieto Sanchis, L. (2013). El Constitucionalismo de los Derechos (The Constitutionalism of the Rights), Madrid, Trotta, pp. 1-312.

10 Esquivel, J. (1972); op. cit., pp. 142-145; SARTORI, G. (1998). Ingeniería Constitucional Comparada (Comparative Constitutional Engineering), México, FCE, p. 1-261. 
kind of order were to exist in the world, it would come not from men, but God. The strength of this conception of power and the right to govern has been one of the most powerful in history. The crisis of this conception of the law, like many other medieval ideas, would come with the Renaissance (XVI century). It was Machiavelli, in The Prince, who made a severe criticism of the idea that the ultimate sovereign in political issues is God. The description made of the relations of power as a result of the virtues (not moral but practical) and strategies for real men paved the way for the idea that laws are derived from the will of men and not of God. Machiavelli, when politics was secularised, opened the door to political modernity. Certainly, the loss of God as a criterion of justice forced us to seek new grounds for political power and its laws. Authors such as Hugo Grocio and Thomas Hobbes named some of them. The first, in his work «De jure belli ac pacis» ${ }^{11}$, trying to justify the existence of certain principles that should govern relations between nations, updated the concept of natural rights (coming from the Middle Ages) by linking it with the idea that sovereignty was an attribute of the States. The idea that there are natural rights that are not lost with the contract would not take long to appear, and it would be towards the end of the seventeenth century when the philosopher John Locke would reformulate the theory of contract from the notion of indispensable individual freedom. With it would appear the first formulation of the Rule of Law. ${ }^{12}$ This English thinker would step forward to propose that this legitimacy was not only, as Hobbes asserted, at the origin of government and laws, but also in its control and monitoring by citizens and civil society. ${ }^{13}$

Locke's political ideas offer two distinctive features of the concept of Rule of Law. On the one hand, it is believed that the law emanates from the will of the citizens and aims to guarantee the exercise of their fundamental freedoms and rights. On the other hand, there is the definition of government as an agent of citizens whose power is limited by the conditions that constitute its origin, that is to say, by the natural rights of individuals. It is important to emphasize, at this point, that the Rule of Law is only legitimate if it is supported by acts of free choices of citizens. Consequently, the law lacks legitimacy if it is not supported by the decision and surveillance of citizens.

The mere respect for the law only states a «relation of the domain» of agent $A$ over agent B; what Locke's doctrine adds is the rationale for that domain. With this interpretation, he established a political doctrine called liberalism, focused on the inseparable notions of individual rights and limited government. Thus, the omnipotent figure of a despotic government could impose appropriate laws that it deemed

11 Grotius, H. (1625). The Rigths of War and Peace. Indianapolis: Liberty Fund.

12 Hervada, J. (1996). Historia de la Ciencia del Derecho Natural, Pamplona, Universidad de Pamplona, pp. 1-344.

13 MÉndez, R. (2013). «An Introduction to Institutional Coordination as An Alternate Model for Neo-Institutional Economic Analysis». Procesos de Mercado Revista Europea de Economía Política, vol. 2, pp. 151-200. 
to be delegitimized on all subjects, and, instead the legitimacy of government and laws as an expression of the citizens freely associated were defended. ${ }^{14}$ The existence of natural human rights whose protection is the only legitimate function of government, but then restrict the quality of citizens only to property owners, eliminates the possibility of political participation and thus exercises their basic concept of most human rights of the population. However, the notion of law had been postulated in a key that will never be abandoned: his justice linked to public decisions and to certain basic human rights.

In the mid-eighteenth century, French philosopher Jean-Jacques Rousseau would add new ideas to this notion of law as citizen sovereignty. ${ }^{15}$ Based on a similar notion to that of Hobbes and Locke, Rousseau's social contract was also raised as an output of the state of nature and the inauguration of the politically organized society. However, the social contract of Rousseau posed no waiver (Hobbes) or delegation (Locke) of the natural liberty of individuals through the social contract. For Rousseau, men are free by nature, and the renunciation of this freedom would mean to renounce their human condition.

The proposed solution by Rousseau is: if all men give up their natural freedom and put it into the hands of society (which is constituted by this waiver), but not in the hands of any particular individual, they will receive from society the same freedom they have given, only now reinforced and protected by the community. In other words, men receive civic or political freedom in exchange for their natural freedom. Freedom is not lost at any time; rather, it is enriched to allow the full human development of all contracting parties. Again, unlike Hobbes and Locke, Rousseau does not grant sovereignty to any ruler, but keeps it in the social body created by the contract; therefore, the only sovereign are the people themselves, e.g. the political community. Every decision, every rule, and every public action should come from this deliberative and executive community. Thus, each of the members now becomes a citizen not to obey anyone in particular (because no one in particular commands) but will continue obeying themselves (because every act of the political community is seen as belonging to each individual). The general will, whose objective is not the private good of individuals or groups but the common or general good, is expressed by laws. These laws are fully legitimate because, coming from the voluntary agreement of men, they simultaneously express the shared interests of all men. The laws of individual freedom and social welfare are identified without being subjected to contradiction because, in the opinion of Rousseau, individual freedom can only be fully exercised within the framework of the general public will that ensures conditions that make this possible. ${ }^{16}$

14 MÉndeZ, R. (2013); op. cit., pp. 151-200.

15 Hernández, J. L. (1987). «El problema del derecho natural en J.J. Rousseau». Anuario de filosofía del derecho, vol. 4, pp. 539-562.

16 Daros, W. R. (2006). «La libertad individual y el contrato social segun J.J. Rousseau». Revista Filosofia, vol. 44 num. 111-112, pp. 115-128.

(C) UNED. Revista de Derecho Político

N. ${ }^{\circ} 109$, septiembre-diciembre 2020, págs. 373-400 
One of the most precise definitions of the concept of Rule of Law in modern thought is probably in the work of the philosopher of the late eighteenth century, Emmanuel Kant. ${ }^{17}$ This thinker tried to justify fully the grounds of public laws on reason and individual freedom; he culminates modern social contract tradition adapting to a justification of the law from the notion of the moral autonomy of individuals. This autonomy means nothing more than the absence of external dependencies on moral judgment and, therefore, the freedom and moral responsibility of individuals. Although Kant develops a whole previous argument of moral order that will serve as the basis for his conception of politics and laws, here, we will leave only the Kantian idea of self-legislator reason, that is, their idea that the natural freedom of men is characterized by the ability to equip themselves with moral and legal laws that guide their practical behavior properly. ${ }^{18}$

If a state can only be the union of free men under legal norms, we already have the essential element of the Rule of Law: the «judicialization» policy. When politics are governed by general and abstract legal norms, it will result in the protection of individual rights through a coercive political power and the limited government performance by the citizens' rights. The most important factor that guarantees these rights is the Constitution conceived as a fundamental law whose principles oversee the freedom of citizens:

The fact that there is a law and/or approved constitution that is formally administered, does not imply 'Rule of Law'. There may be a law, which does not limit the power, but it is an instrument of power. In that case, we are not in a 'rule of law', we are facing a 'state of law'. ${ }^{19}$

So then, no legal system that lacks the minimum requirements reviewed by liberal thinkers could be a genuine Rule of Law. Throughout history it shows that for many years, men's will be above the law. The modern idea of Rule of Law arises in nascent form in the late eighteenth and early nineteenth centuries, when the foundations of world revolutions impel to overcome the absolutism of the monarchy through democratic regimes, in which the authoritarian power replaced the monarch with a ruler elected by the people and subject to the restrictions, rights and obligations imposed by the legal systems that sought to protect the freedom of men.

The Rule of Law represents the confluence of different principles and, established by various thinkers, philosophical and political movements and historical forces, principles which are embodied in a set of structures and institutions that only in recent times have been recognized as congruent elements of a model: The Western Liberal State. So then, the concept of Rule of Law is a response to the absolutist state,

17 Cantillano, H. M. (2014). «Aporte de Kant al concepto Moderno del Estado de Derecho». Revista Jurídica IUS Doctrina, vol. 2 num. 3, pp. 1-27. $57-77$.

InNerarity, D. (1987). «Libertad e historia en Kant». Thémata, Revista de Filosofía, vol. 4, pp.

19 GHersi, E. (2009); op. cit., pp. 1-9. 
characterized by the absence of freedoms, the concentration of power and the irresponsibility of the holders of the organs of power. ${ }^{20}$ Hence the legal guarantee of the Rule of Law applicable to modern constitutionalism. During the twentieth century, the Rule of Law was established as a counterpoint to totalitarianism. The totalitarianism was characterized by the suppression of individual and public freedoms, including the outlawing of parties, deliberative bodies, and freedom of transit, assembly, and expression. However, the totalitarianism sought to legitimize through legal instruments. $^{21}$

The concept of Rule of Law is not supported by Kelsen, for whom there is an identity of the state order and the legal order. The rule of law is a kind of state considered as a concept of political, legal and moral theory that defends the premise that government authority may only be carried out according to written laws, which must have been adopted through an established procedure. ${ }^{22}$ No State or rights constitute a rule of law; only, that state controlled by the law and that legitimate law (democratic). To summarise, the Rule of Law is that state in which authorities and individuals are governed by law, and it incorporates the rights and fundamental freedoms and is applied by impartial and accessible institutions that generate certainty.

\section{RULE OF LAW AND SOFT RULE OF LAW}

An order or system of organization is essential to bring together knowledge (information) and legal knowledge in particular. Therefore, a system for organizing this legal knowledge can be developed from mechanisms such as rules. ${ }^{23}$ This contributes to the knowledge in this area and ensures that it does not remain discrete and inaccessible. ${ }^{24}$ This means that in the legal field, it is also possible to speak of an efficient and effective mechanism for signaling the order (Rule of Law). This type of mechanism allows a legal organization system and achieves objectives. If it is replaced violently and / or irrationally; there would be a problem with the knowledge.

20 Les Benedict, M. (1985). «Laissez-Faire and Liberty: A Re-Evaluation of the Meaning and Origins of Laissez-Faire Constitutionalism». Law and History Review, vol. 3 num. 02, pp. 293-33

21 Ghersi, E. (2009); op. cit., pp. 1-9.

22 Following Les Benedict, M. (1985); op. cit., pp. 293-33, but according to Zimmermann, A. (2014). «Waiting for the Rule of Law in Brazill: A Meta-legal Analysis of the Insufficient Realization of the Rule of Law in Brazil», Silkenat, J., Hickey J. and Barenboim, P. (eds.), The Legal Doctrines of the Rule of Law and the Legal State (Rechtsstaat), New York, Springer Nature, pp. 331-347, this is important because: «although the meaning of a concept such as the rule of law is open to debate, there is a general agreement that is essentially concerned with protecting the individual from unpredictable and arbitrary interference with their vital interest».

23 North, D. C. (1990). Institutions, Institutional Change, and Economic Performance. Cambridge: Cambridge University Press, pp. 15-152.

24 Hayek, F (1979). «The Road to Serfdom» (Sixth chapter: Planning and the Rule of Law), Hamowy, R. (ed.), The Constitution of Liberty, Chicago, The University of Chicago Press, pp. 101-107.

(C) UNED. Revista de Derecho Político

381

N. ${ }^{\circ} 109$, septiembre-diciembre 2020, págs. 373-400 
This is precisely the kind of problem that stems from excessive control of individuals' actions (allocation of rights) and is expressed in the establishment of a closed system of legal planning by the government (Soft Rule of Law). ${ }^{25}$ The prevalence of this closed system affects civil society and its essential component, the individual, as has been described in Table 1 .

This review allows us to infer the need for a system where the Rule of Law prevails over the Soft Rule of Law. This proposal of an environment where an open order prevails and is not subject to central planning or the mandates of the ruling can be linked to that called the «spontaneous organization system of social activity» ${ }^{26}$. For this, it is essential to consider other aspects such as a vision of social cooperation among freemen and the requirement of an open order developed from reasonable legal and moral rules. The latter is then established as a component of the «basic necessity» for peaceful coexistence, understood as a condition inherent in any model that pursues growth and the political, social and economic development of a country.

The above can argue that the prevalence of the Rule of Law expressed through a macro device such as the constitution or law of laws, is not equivalent to the prevalence of an irrational rule where the government of the day establishes rules by decree and under the cover of a constitution which is shown as a useful device to formalize the establishment of privileges, that is to say, unequal treatment for all. This is so, although there may be technical reasons holding all kinds of 'positive' demonstration, even the Soft Rule of Law is an expression of a prone collective likely to be corrected or self-developed through its own internal rules.

The idea of the prevalence of a Rule of Law that reflects the prevalence of general rules of conduct must be the product of cultural evolution and knowledge (or information) that individuals acquire over time through trial and error. This is distinguished from the model Rule of Law understood from the proposal of authors such as Hume. A constitutional model governed by a Rule of Law can be expressed through the rescue of the values of liberalism of the XIX century ${ }^{27}$ and is based on a spontaneous evolution that is the product of human actions but not of human design.

If it is considered that order or system of organization is essential for binding legal knowledge, it must also be considered that individuals in the exercise of freedom, take action (juridical) based on the information they have and this information

25 However, it is used by well-meaning people. It is often belittled and presented under the label of thought or expression related to outdated nineteenth-century ideas, i.e. ideas overtaken by the more progressive literature.

26 Vid. HAYEK, F (1979); op. cit., pp. 101-107.

27 As argued by HaYeK, F (1979); op. cit., pp. 101-107.

The rules of just conduct are, with some exceptions, related to family law, negative rules, according SARTORI, G. (1998); op. cit., p. 1-261, because what they do is prohibit unfair conduct by individuals. They cannot simply impose behavior (positive rules) unless through their actions they have taken responsibility for doing something positive. The rules of conduct must not confer rights on individuals. Rather, they must establish the conditions under which people can acquire those rights. 
must reach an integrated character that in its essence is characterized for being scattered in pieces and incomplete.

This becomes more important when it brings up the role of Rule of Law. A formal analysis of that part of its development, in reality, cannot be confined to the establishment of abstractions that evoke the so-called equilibrium model expressed mainly through tautologies. The empirical element of the Rule of Law, therefore, consists of propositions about the acquisition of information and technical assumptions that are not inspired by radical legal positivism.

This is the case due to the concept of equilibrium that is only valid within the scope of the individual and the actions of this as part of a plan. It makes no sense to speak of equilibrium applied to a (competitive) society organized through an open order or Rule of Law, where individual acts according to their plan and the information it holds. ${ }^{28}$ Thus, an individual can be balanced, but a group of individuals and an organization system could not be unless one person (dictator) makes all decisions over others or the plans and/or activity (legal) of all of them are compatible because they are based on the same expectations and the same information. So, there can only exist a tendency toward equilibrium, that is, under certain conditions, the information and intentions of the different members of society could achieve some degree of compatibility. But for there to be a real balance in the legal system, this would have to be perfect, that is, that all information must be known as soon as it originates in its entirety and without being prone to error or possessing any hermeneutical mistakes. Thus the prevalence of a scenario of Rule of Law is identified with a scenario where the spontaneous actions of the individuals come first in full exercise of their rights (e.g. Civil Liberties) and not a scenario of Soft Rule of Law that results from a single plan (product of social mind) that can theoretically exist only in a totalitarian state.

Introducing a critique of closed organizational systems means criticizing the existence of environments where a Soft Rule of Law prevails in a scenario that is characterized by the problem of legal planning. All government activity is the product of legal planning, based naturally on the information that the ruler possesses. The question is, whether to plan through a closed system or through a framework of rules with a valid propensity of general and abstract mechanisms where institutional competition is present and so rules are understood from a parameter of evolution and/or involution not run by a social Darwinism.

From the above, it is considered that a system where the Rule of Law prevails is superimposed on an organized system through attached guidelines to the Soft Rule of Law because it allows better use of existing juridical information without coercing negative rights and denying the existence of particular circumstances of time and space. This relates to society with its mechanisms of legal governance addition and provides a system where the Rule of Law prevails and contributes to the rapid adap-

28 According to HaYeK, F (1979); op. cit., pp. 101-107. 
tation of their different social components through its signaling mechanisms (social cooperation between agents) and is rooted in an element such as social legitimacy at the expense of legal interventionism.

Based on the established laws, the role of the government should be limited primarily to provide the framework in which individuals can freely pursue their objectives in a coordinated manner. When the common man, although he does not possess any power, can engage freely in cooperative activities with other men, this can only produce good things such as the eradication of subservience and political patronage. ${ }^{29}$ This, in turn, provokes the empowerment of economic freedom (e.g. Free enterprise), competition, private property and limited government.

This is important because without freedom in economic matters there cannot exist personal and political freedom tutored by legal rules. A feedback process occurs where issues such as economic freedom open doors so that there is free use of information (new knowledge) which settles the system of legal organization (Rule of Law) and makes major advances in a society multiply exponentially, regardless of aspects rescued by other authors such as the struggle between social classes, domination and others.

An approach like the one proposed that was developed from the methodological subjectivism does not criticize the goals of equality and justice pursued by the legal order. Choosing not to question the preponderance of a system where the Soft Rule of Law stands is considered the most successful way to try and achieve goals «socially relevant». ${ }^{30}$ In this regard, it states that a system should prevail in which the coercive power held by the government is limited to creating the conditions under which individuals can develop their initiatives and plan more successfully or if the rational use of tangible and intangible resources are inherent in themselves.

The establishment of a system where a scenario of Rule of Law is prevalent means that government, in all its actions, is restricted by the rules fixed and announced beforehand. This makes it possible to predict with relative certainty how the government will use its power of coercion under given circumstances and allows the individual plan according to their knowledge about how the government will present it. There is, then, room for arbitrariness, prerogative and discretionary authority. When an individual knows the rules of the game, they are free to pursue its goals with the confidence that the government's power will not be used to thwart their efforts. As soon as the government begins to arbitrarily change the rules and to balance interests against each other, it begins to affect civil society and their inherent rights. Therefore, in a scenario of Rule of Law, it emerges that the rules are effective and legitimate when always applied in the same manner, without exception; that is, without pursuing the benefit of a specific group to the detriment of the rest. However, there is protection on legal-social technicalities.

29 GHersi, E. (2009); op. cit., pp. 1-9.

30 Méndez, R. (2013); op. cit., pp. 151-200. 
Therefore, the Rule of Law is not synonymous with the power of the government to legislate. This introduces a difference with a system of Soft Rule of Law where the actions of a government can be legally valid but fail to conform to the law and its general principles. This difference means understanding the limits of the law when it is directed towards a particular group, whether to encourage it or to discriminate against it. A system of Rule of Law is one that is governed by rules of just conduct where no concept of unlimited government stands. It aims to allow individuals to achieve their goals or objectives in conditions of freedom. ${ }^{31}$ These are conditions where everyone can use the information, they have to attempt to achieve their targets without affecting general principles of good governance whose primary search is the protection of freedom. It, therefore, rejects the mere transfer of vague rules and safe behavior. This means that a system of Rule of Law should not necessarily be delimited through being exposed by authors such as Bacon, Hobbes and Austin: social constructivism and the belief that there is a supreme authority, monarch or democratic assembly, with power unlimited and all that this legislator supreme decree is a law and only it can enact proposed changes. In other words, only it can make the law (constitution) into an instrument to use power instead of what should limit the use of power. A system of Rule of Law then also diverges from a system of Soft Rule of Law as it is effective as a power to legislate; it is effectively limited by legitimate institutional padlocks from the social point of view and not merely legal. ${ }^{32}$ As explained, it means that in a context of Soft Rule of Law, instruments such as the constitution fail to confine to the organizational rules of government but allow the emergence of a superstructure that supports rules that directly or indirectly and repeatedly limit citizenship without plausible justification as the generation of «real negative externalities» ${ }^{33}$ or asymmetric transfer of social costs. ${ }^{34}$

\section{HUMAN RIGHTS AND THE RULE OF LAW}

The above definition is achieved to identify clearly which requirements are necessary for forming a Rule of Law. Among the elements, we can say that this «separation of powers» is a basis for the distribution of power in different functions and ensures that the state power is not concentrated in a single institution, but it is distributed, allowing greater efficiency and proper controls avoiding arbitrariness and

31 HaYeK, F (1979); op. cit., pp. 101-107.

32 Therefore, the Rule of Law represents the pathway through which the emergence of an ideal constitution becomes feasible, that is, one that manages to provide the greatest possible freedom to organize the laws so that the freedom of each one can coexist with the freedom of all.

33 Posner, R. A. (2014). Economic Analysis of Law, Madrid, Fondo de Cultura Económica de España, pp. 16-752.

34 Ghersi, E. (2009); op. cit., pp. 1-9.

(C) UNED. Revista de Derecho Politico

N. ${ }^{\circ} 109$, septiembre-diciembre 2020, págs. 373-400 
the abuse of it. In ancient times, the appropriateness of the control and balance of power was addressed through confrontation and the cooperation of various forces.

However, unlike the old conception, where the elements of the «mixed constitution» can be linked to groups and defined social classes (e.g., nobles and commoners), the modern view takes as its starting point the differentiation of functions and, consequently, organs within the institutional apparatus of the state which have become relatively autonomous from society. «Power ought to serve as a check to power ${ }^{35}$ remains the principle of the separation of powers, whether it should take a more confrontational style, as in the presidential system of the United States, or a more cooperative one, such as in the European parliamentary regime. ${ }^{36}$

Another element is the Rule of Law, which provides legal certainty and security, that is, the ability to calculate the consequences of their actions concerning to other individuals or in connection with public power. With this element, we understand obedience to the established rules, because the rules should be an expression of the popular will and must submit to it both rulers and those who are ruled, the principle of legality: Every act of the state organs must be founded and motivated by the law in force. That is, that every act of public authority must be based on an existing legal standard and, further, that statute must find its way of living at a higher standard. The principle of legality responds to the contrast between the government of men and the Rule of Law, according to which, in the first case, the governed are unprotected against the discretion of the ruler and, secondly, subjects have means of understanding the limits and scope of the exercise of authority. This dichotomy involves a value judgment: in the case of the governed, legality prevails where they enjoy certainty and legal security and there is, in principle, equality before the law (Greek ideal of isonomy); where the law is a principle absent, the rulers have absolute discretion to affect the lives of their subjects.

Another element has also been identified; there are institutional guarantees of certainty, fairness and access, which means that the dynamic aspect of the law (application of rules to specific cases) is executed by impartial and accessible institutions (previously established courts) that generate certainty through procedures accessible for all (equal access to justice) and aim to ensure that all penalties are founded and motivated in law. That is, the authorities can do nothing that is not covered by the law; any possible involvement of individual rights must be properly grounded and justified by a rule, while the affected should have the opportunity to defend themselves and to be heard (right to a hearing or principle of due process). It should be noted that this feature is undoubtedly at the heart of every modern constitutional state since in the application of laws and effective daily relations of the regulatory body, these are subjects under their rule.

35 Montesquieu, C. D. S. B., Carrithers, D. W., \& Baron de Montesquieu, C. D. S. (2001). The spirit of laws, Batoche, pp. 20-714.

36 De Vergottini, G. (2005); op. cit., pp. 1-908. 
An essential element of the Rule of Law is: The recognition of the fundamental rights and freedoms of individuals, and the establishment of safeguards to ensure their effective protection. The Rule of Law refers to a particular institutional design to protect and guarantee the fundamental rights of persons, intended to guide, control, and limit the exercise of public power through general rules, which make up a clear and known system for all.

As we have seen, the situation of human rights is in vogue and it is no surprise that now this respect and these guarantees are given within an orderly and dutiful legal framework that also provides the mechanisms or resources that can be brought in cases of abuse or some violation of these rights. For French and American revolutionaries, the protection of human rights was the foundation and purpose of social institutions. There are innate rights prior and superior to the State and only it can recognize rights. However, to secure them and as a form of guarantee, these rights are proclaimed solemnly in a statement so that the acts of the legislature and the executive can be compared at any moment to the aim of any political institution, and are most respected; so that the complaints of citizens, founded henceforth on simple and indisputable principles, always contribute to the maintenance of the Constitution and to the happiness of all. If these criteria are met, the chances of the governed achieving acceptable levels of legal certainty and security will increase. However, we can still go further: to some scholars, the Rule of Law must involve the democratic principle and the notion of fundamental rights. From this perspective, the concept takes on a broader dimension: it is a democratic Rule of Law because the existence of standards with certain characteristics is not enough; they must be the indirect expression of the popular will.

So, stable, clear public and general laws that are issued by a popularly elected Legislative Power who contemplate the fundamental human rights, paired with a fair judicial system, whose judges (applicators of law) are aligned to legal procedures that found and motivate their sentences, is the formula that results in a democratic rule of law.

\section{RULE OF LAW AND DEMOCRACY}

The concept of Rule of Law gives us a comprehensive reflection on the field of politics, the values and legal principles; primarily on the basic structure of society, that is to say, in the system of basic institutions that allow the qualification of democracy for a given society. The truth is that there are democratic and legal societies where wealth distribution is more limited than in others, or where the criteria for establishing penalties could be considered as being excessively severe; but it is not the distance between authoritarianism and democracy, but a distance within the model itself of Rule of Law. 
There are, indeed, vast differences between social systems of different democratic countries, although these differences have more to do with the institutions of distributive justice and social services than with the legitimacy of the law. Some seem fairer to us, others more restrictive, but they all share a similar legal structure that allows us to classify within the grounds. Therefore, it is necessary to emphasize that the Rule of Law is not equivalent to social justice, but, and this is essential, any reasonable model of social justice can be achieved only through the channels of the Rule of Law.

Similarly, democracy is not equivalent to an equitable distribution of wealth; only by democratic powers is it possible to distribute social wealth without serious injustice and bloodshed. In any event, the Rule of Law promotes abundant space for the reform of existing institutions and the search for legitimate social projects that are supported from the plurality of collective life. ${ }^{37}$

The Rule of Law collides with totalitarian and authoritarian systems, e.g. the systems where there is no effective control over the government and the basic rights of citizens are not respected. Its basic principle is that not all law is desirable, even if it is effective. History has recorded legal systems that cannot be considered genuine Rule of Law. ${ }^{38}$ The legality established by the Nazi government (Nationalsozialstischen Rechtsstaat), the legality of Franco (the Fundamental Laws of the State) and the legality of the organized communist countries politically and legally, from the assumption of the revolutionary party supremacy, are examples of legal systems, all with good performance and prolonged application, which could not be described as Rule of Law. ${ }^{39}$

Democracy is made, then, as a model with four dimensions, each corresponding to the four types of fundamental rights; political rights, civil rights, rights of freedom and social rights. The first two types of rights, called secondary, formal or instrumental rights, place legitimacy in the sphere of politics and economics, and therefore, formal and multi-dimensional political civil democracy. The other two types of rights (of freedom and social) are called primary; substantial or final framework that can do what is forbidden to the political and economic empowerment of people, basing the legitimacy of the substance on the decisions and so on the substantial dimension of democracy. The political dimension is the basis of the other three, in the absence of which one cannot speak of democracy. However, it is insufficient to define democracy, so it requires the four dimensions together to discuss constitutional democracy,

37 Ghersi, E. (2009); op. cit., pp. 1-9.

38 O’donnell, G. (2005). «Democracia y Estado de Derecho» (Democracy and the Rule of Law). Nexos, vol. 325, p. 19.

39 ZimmermanN, A. (2012). «Marxismo, comunismo y derecho: cómo el Marxismo llevó al desorden y al genocidio en la antigua unión soviética». Revista de Economía y Derecho, vol. 9, p. 34; ZimmermanN, A. (2010). «Evolutionary legal theories: the impact of Darwinism on western conceptions of law». Journal of Creation, vol. 24 num. 2, pp. 103-111; ZIMMERMANN, A. (2008). «The Politics of Lawlessness in Brazil: How Brazilian Politics overrides the Rule of Law». ELaw - Murdoch University Electronic Journal of Law, vol. 15 num. 1, pp. 3-42. 
based on which eludes all decisional power, both public and private and the availability of fundamental rights as a whole.

The paradigm of constitutional democracy was imposed after the Second World War to prevent experiences of the Nazi or fascist type from being broken hereinafter. The consequences of this model are that citizens become holders of fundamental rights. Therefore, people acquire an over-ordered location to set public and private powers, which are linked to fundamental rights, where sovereignty resides in the only sense in which it is still permissible to use this old word. The substantial concept of democracy ${ }^{40}$ places democracy in a policy area: model as embodied in their respect and subordination to the rigidly established Constitution. This substantial democracy is the necessary complement of formal democracy (polyarchy), because democracy is the form, but also the substance.

\section{RULE OF LAW AND CONSOLIDATED DEMOCRACY}

The main political challenge of consolidating democracy to enforce the Rule of Law is to equalize the concepts of legality and legitimacy, to clarify the concept of democratic and legitimate (different from authoritarianism) and encourage civic authority to enforce the government actions. ${ }^{41}$

Matching the concepts of legality and legitimacy is not only a task of government, where the legitimacy is the result of the law, but also the general public should support the establishment of legality as an indispensable element of social demands. Therefore, the public must banish the idea that only a few can enforce the Rule of Law; they must rely on their institutions and assert their right to demand accounts based on the law that gives the Rule of Law, which the supposedly democratic regime built. Thus, the biggest challenge is to abide by the Rule of Law by promoting changes that become fairer and equitable compared to their subsequent legitimacy.

Thus, the application of the Rule of Law in Ecuador and Peru must go hand in hand with overcoming a legitimacy based on impunity and the negotiation of law. On the other hand, the socio-economic challenge to close the gap of inequality and poverty implies the implementation of effective policies and non-welfare, eradicating populist discourse at the time of its implementation, strengthening the enforcement and administration of justice, effectively combatting poverty by improving the effective public investment in education, health and housing, and improving the overall safety of the population.

Without these previous political and social changes, it is impossible to assert the Rule of Law and a democracy without Rule of Law is a fragile, unsustainable and

40 Proposed by Ferrajoli, L. (2004). Derechos y Garantías. La ley del más débil (Rights and Guarantees. The law of the weakest), Madrid, Trotta, pp. 15-177.

41 Ghersi, E. (2009); op. cit., pp. 1-9.

(C) UNED. Revista de Derecho Politico

N. ${ }^{\circ} 109$, septiembre-diciembre 2020, págs. 373-400 
inequitable one. Thus, democratic consolidation requires legality and the legitimacy of governments, requiring careful public accounts, economic and social development, institutional strength and a new culture of legality.

\section{VI.1. Rule of Law and State Reform}

For some authors, the role of constitutional law in complex societies of our time should be reduced to serving as a channel and ensuring the conditions of political exchange or the public sphere of discussion ${ }^{42}$, or to regulate the procedures to maintain political pluralism. This would ensure that the political majority occupied at any given time and the government cannot block the passage to minorities who may want to enter in the future. ${ }^{43}$

Some authors offer a more demanding vision of the role of constitutional law in democratic states. For example, that fundamental rights, which are essential elements of any constitutional state, are something like the «substantial part» of a democracy, as they have what the government should do (e.g. social rights) or cannot do (e.g. restricting rights of freedom). ${ }^{44}$ Fundamental rights are characterised «precisely because they are equally guaranteed to all and withdrawn from the market availability and politics (...); and act as actors not only legitimately but also, and above all, as factors of legitimization of decisions and non-decisions». ${ }^{45}$

In fact, a solid Rule of Law instead of Soft Rule of Law is essential for any democratic regime because: «The rule of law is a cornerstone of any democracy of good quality» ${ }^{46}$. Therefore, what does legal regulation add to democratic pluralism? Firstly, stability. Secondly, predictability. Thirdly, it is through legal rules as the place and role of each of the acting subjects in a democratic context (political parties, public authorities, citizens, media, etc.) is delimited.

What could bring the law and specifically the constitutional law to the process of the development of democratic systems such as Ecuador and Peru? Surely a great deal, because the legal and constitutional institutions require a consolidated democracy. This scenario is still far from being achieved in these countries. That is why in these countries they are still currently discussing the 'state reform' and the prevalence of the Soft Rule of Law over the Rule of Law.

The state reform may have an impact on the democratic quality of Ecuador and Peru if it can solve at least the following scenarios:

a) Better regulation of fundamental rights; even more, adequately enunciating some rights that already exist and are incorporating others. It is necessary to

42 Habermas, J. (1998). Facticidad y Validez (Facts and Validity), Madrid, Trotta, pp. 12-196.

43 SARTORI, G. (1998); op. cit., p. 1-261.

44 Ferrajoli, L. (2004); op. cit., pp. 15-177.

45 Vid. Ferrajoli, L. (2004); op. cit., pp. 15-177.

46 As pointed out by O'donnell, G. (2005); op. cit., p. 19. 
develop and consider the impact of the right to personal and familial priva$\mathrm{cy}$, the right to honor, and the right to self-image. In the medium term, the possible inclusion of further development of constitutional property rights over natural resources must be considered.

b) The redesigning of the relationship between the branches and levels of government, to introduce incentives for cooperation and not only for the confrontation between powers. To achieve this, the creation of mechanisms such as budget initiatives renewal or urgency (which must be discussed by the legislature within a short period) needs to be considered.

c) Regarding the design of the government system in Ecuador and Peru, it would have to weigh the necessity of moving to a system where the powers of local authorities are no longer determined by their economic capacity and its management strength.

d) Having better instruments for judicial review that are consistent with the speech that identifies the relevance of having a constitutional court. In Ecuador and Peru, it would require the reformation of the "writ of Amparo» (Peru) or «action of protection» (Ecuador) and would improve the system of constitutional controversies and actions of unconstitutionality. Key issues to be discussed at this point would be at least the active and passive standing in the process of constitutional review, and the effects of judgments.

e) Providing mechanisms to improve public deliberation at various levels and instances, for example, through the enlarged standing to 'writ of Amparo' or 'action of protection' and constitutional review procedures.

Departing from a comparative experience, is it necessary to build a new constitutional model for Ecuador and Peru? The question that is relevant now, in light of what has just been discussed, is whether the necessary reforms can be made under the current constitutional framework or whether it is necessary to move towards new texts.

This is an important topic on the agenda of Ecuadorian and Peruvian constitutionalism. In recent years, it has been discussed whether or not these countries need a new constitution in light of the challenges that the evolving political and social scenario currently requires. The positions are divided on the matter because, while for some doctrine there is nothing salvageable in their current constitutions, for others the debate on constitutional renewal is secondary and should be addressed within the next few decades. To summarize, the topic of constitutional renewal in Ecuador and Peru can be divided into three main positions. The first argues the relevance of continuing with the current constitutional models, adapting if at all, with small changes in character, especially under the constitution. Undergoing a major reform process that has been carried out in both cases brought about truly new con- 
stitutional text in the Peruvian Constitution of $1993^{47}$ and the Ecuadorian Constitution of 2008. To that extent, all that would be required are some additional adjustments. For a second position, it requires a total change. The third option maintains that many changes are needed in order to close an era, even symbolically, and to open a new stage in the democratic life of these countries.

In the Peruvian case, the first option, represented by very eminent jurists, does not seem difficult to sustain. The reasons for this are quite simple: Peru has a relatively stable social and political reality and has a constitution that can be fully interpreted. However, the Ecuadorian case refers to a different juridical scenario. Despite the relative political and social stability of Ecuador, there are several rights (e.g. constitutional property rights) that cannot be efficiently protected. Also, for this latest case, there are institutional arrangements that are dysfunctional for partisan balances that arise as a result of the lack of political pluralism. ${ }^{48}$

In conclusion, the need for further research to identify which is the best medium-term solution that can be stated, both from a theoretical and political perspective, will convene to issue a new constitution in the case of Ecuador and to develop better constitutional property rights for Peru. There is no doubt that both scenarios should guide the debate on democratic consolidation and the development of institutional quality for both countries.

\section{SOFT RULE OF LAW IN ECUADOR AND PERU}

Peru and Ecuador are passing through a period of institutional instability that has affected their governance and their guarantees of democratic consolidation so that today it is necessary to question the feasibility of creating a democratic state of law and overcoming the prevailing Soft Rule of Law in both countries.

It may be noted that due to high transaction costs, enforcement and management, the prevailing institutional framework is prevented in practice and an important sector of the population has access to legal certainty and legality, while certain tolerant groups are openly placed above the law. Thus, on the one hand, the costs and benefits of Law are not distributed equitably and, on the other, some fail to comply without facing punishment, which represents an incentive for others to do the same. The seriousness of this situation is that it is mainly the government that disobeys the law.

Paradoxically on paper, the Constitutions of both countries contemplate some elements of a discredited state which overlays a modern state of law. Therefore, the problem in both countries is that they have a clear origin in the design of their rules. This has limited Peru and Ecuador in their attempts to be recognized as countries

47 Rubio Correa, M. (1999). Estudio de la Constitución Política de 1993 (A Revision of the Political Constitution of 1993), Lima, PUCP Fondo Editorial, pp. 177-326.

48 AOKI, M. (2001). Toward a comparative institutional analysis, MIT press, pp. 1-560; FERRAJOLI, L. (2004); op. cit., pp. 15-177.; MÉndeZ, R. (2013); op. cit., pp. 151-200. 
that have exceeded the material poverty and the inequality of economic, social, political and legal framework; asserting them as countries that have managed the implementation and respect for the law. Although, from the standpoint of the «democratic principle», both countries have progressed differently for civil society in the field of respect for the law they are still in diapers. In both countries the law is violated daily, starting with the governors and also the governed: the law is violated for individual benefits or worse, it is violated based on personal conceptions of what the law should be. In both countries, the legal order and justice systems are serious problems. To begin, we can say that neither country has a clear set of principles and rights respected by all. On the contrary, both authorities and individuals often flout the rules, which means that there is no certainty in social interactions. ${ }^{49}$

The application of the Rule of Law requires clear rules, enforceable sanctions, and a culture of legality. Unfortunately, Peru and Ecuador still lack a culture of constitutionality, legality and respect for the Rule of Law to limit the prevalence of a system that reflects and protects the power of the government rather than limiting it. This is important as Hayek analyzed that this «means that government in all its actions is bound by rules fixed and announced beforehand» ${ }^{50}$. From this point of view, data from the Institutional Quality Indexes for 2012, 2013, 2014, 2015 and 2016 shows that Peruvian and Ecuadorian democracy has been cemented to a weak culture of effective protection of fundamental rights such as the right to property. This is the result of the distrust of citizens regarding their institutions (Soft Rule of Law). Also, various traces of authoritarianism limiting voice and accountability are still in force between the population and various socio-legal conditions are adverse throughout the country. Table 1 describes data referring to the prior description below:

Table 1: Institutional Quality Indexes 2012 - 2016

\begin{tabular}{|c|c|c|c|c|c|}
\hline \multicolumn{7}{|c|}{ Institutional Quality Index 2012 } \\
\hline Country & Ranking & $\begin{array}{c}\text { Consolidated } \\
\text { Results }\end{array}$ & Rule of Law & $\begin{array}{c}\text { Voice \& } \\
\text { Accountability } \\
\text { (Democracy) }\end{array}$ & Corruption \\
\hline Canada & 7 & 0,9397 & 0,94 & 0,95 & 0,95 \\
\hline Chile & 22 & 0,8478 & 0,88 & 0,82 & 0,89 \\
\hline Peru & 68 & 0,5598 & 0,33 & 0,50 & 0,57 \\
\hline Ecuador & 144 & 0,2821 & 0,12 & 0,38 & 0,35 \\
\hline Cuba & 188 & 0,1488 & 0,34 & 0,07 & 0,67 \\
\hline
\end{tabular}

49 Aoki, M. (2001); op. cit., pp. 1-560.

50 HayeK, F (1979); op. cit., pp. 101-107.

(C) UNED. Revista de Derecho Politico

N. ${ }^{\circ} 109$, septiembre-diciembre 2020, págs. 373-400 
RUBÉN MÉNDEZ REÁTEGUI - OSCAR SUMAR ALBUJAR

\begin{tabular}{|c|c|c|c|c|c|}
\hline \multicolumn{6}{|c|}{ Institutional Quality Index 2013} \\
\hline Canada & 7 & 0,9315 & 0,9474 & 0,9559 & 0,9524 \\
\hline Chile & 22 & 0,8436 & 0,8821 & 0,8019 & 0,8814 \\
\hline Peru & 60 & 0,6174 & 0,3302 & 0,5377 & 0,5367 \\
\hline Ecuador & 143 & 0,2907 & 0,1226 & 0,3368 & 0,4294 \\
\hline Cuba & 176 & 0,1420 & 0,3255 & 0,0802 & 0,6497 \\
\hline \multicolumn{6}{|c|}{ Institutional Quality Index 2014} \\
\hline Canada & 6 & 0,9398 & 0,9474 & 0,9559 & 0,9524 \\
\hline Chile & 22 & 0,8278 & 0,8804 & 0,8039 & 0,8690 \\
\hline Peru & 68 & 0,5596 & 0,3349 & 0,5147 & 0,4821 \\
\hline Ecuador & 144 & 0,2895 & 0,1388 & 0,3971 & 0,3690 \\
\hline Cuba & 188 & 0,0112 & 0,3254 & 0,0686 & 0,6726 \\
\hline \multicolumn{6}{|c|}{ Institutional Quality Index 2015} \\
\hline Canada & 7 & 0,9333 & 0,9481 & 0,9481 & 0,9486 \\
\hline Chile & 22 & 0,8417 & 0,8774 & 0,8443 & 0,9486 \\
\hline Peru & 63 & 0,6072 & 0,3349 & 0,5094 & 0,4743 \\
\hline Ecuador & 151 & 0,2650 & 0,1840 & 0,3915 & 0,3690 \\
\hline Cuba & 173 & 0,1426 & 0,3208 & 0,0991 & 0,6457 \\
\hline \multicolumn{6}{|c|}{ Institutional Quality Index 2016} \\
\hline Canada & 6 & 0,9398 & 0,9474 & 0,9559 & 0,9524 \\
\hline Chile & 22 & 0,8278 & 0,8804 & 0,8039 & 0,8690 \\
\hline Peru & 68 & 0,5596 & 0,3349 & 0,5147 & 0,4821 \\
\hline Ecuador & 144 & 0,2895 & 0,1388 & 0,3971 & 0,3690 \\
\hline Cuba & 188 & 0,0112 & 0,3254 & 0,0686 & 0,6726 \\
\hline
\end{tabular}

Source: Fundación Libertad \& Progreso (Progress \& Freedom Foundation)

We see an example in the economic rights enshrined at the constitutional level in both jurisdictions, the law formally establishes an explicit prohibition of private monopolies, while it was decided to privatize public corporations without mechanisms to ensure competition fully. ${ }^{51}$

51 Méndez, R. (2014). «Una nota crítica a propósito del libro Why Nations Fail. The Origins of Power, Prosperity, and Poverty». Lecturas de Economía, vol. 80, pp. 211-218. 
The current situation of the Rule of Law in both countries regarding the essential elements concerning the respect and guarantees of the fundamental rights that have been verified are very serious issues of the violation of human rights, mainly by the police and army that include the illegal detention, torture and killing of people. This situation has only been aired before the judiciary without ever reaching a real cleansing by International Transparency of the corruption that plagues both countries. First, because of the difficulty of proving such illegal acts procedurally. Secondly, it has been difficult for the judiciary to issue effective penalties, since many of the injured people belong to low-income groups and thus is not in a position to meet the costs of litigation and hire lawyers of respectable quality. Finally, the problem of widespread corruption far exceeds in scope, case by case, the court sentences.

The seriousness of the violation of human rights is such that it was necessary to create an agency dedicated exclusively to research and to control such abuses similar to those that exist in other countries under the name of «Ombudsman» (attorney or representative of the people, in Swedish). However, these agencies have been incapable of addressing the issues of the violation of human rights and the institutionalization of corruption.

Hence, this does not constitute an «initial social pact» in the contractual language of philosophers and liberal thinkers, but an amalgam of often irreconcilable political projects, if the constitutions of both countries do not constitute a coherent legal system, it cannot be expected that laws in general, and the administration of justice in particular, address the challenge of modernization.

In short, one can see that Ecuador and Peru, despite the many efforts that have been made, have not managed to establish a government that meets these minimum requirements of effectiveness and legality. Despite the lack of a judiciary capable of imposing order to bureaucracy and individuals to be subject in all cases to law, there is not, paradoxically, the problem of widespread violence or anarchy. In large part, this is because there are other extra-legal mechanisms and informal arrangements for conflict resolution.

\section{CONCLUSION}

Personal autonomy itself, one of the values that sustain democracy and justifies the Rule of Law, is the best guarantee that we can believe in to ensure that people create the potential of democracy. In this way, the Rule of Law continues to provide an essential service, hence its absolute importance.

The view supported in this document constitutes a commitment in favor of democracy, an approach that transits through the Rule of Law. Firstly, the deepening of this is an alternative way, one of undisputed importance, to advance democratic consolidation, whilst also deepening its quality. 
Secondly, both democracy and the Rule of Law are betting on the autonomous individual: endowed with rights, intelligent, knowledgeable, able to decide, able to carry out their own decisions. The Rule of Law acts as the defense of fundamental rights, the same as is required for democracy. Therefore, through the expansion of personal autonomy, the Rule of Law reinforces the conditions that make democracy possible, and through them, it strengthens and deepens democracy itself.

Through the autonomy of people, democracy can build public truth through dialogue and consensus-based on beings' hindsight, experiences, and different ideas. Thus, democracy cannot bet on forbidden hunting grounds or areas of the undecidable. It will deny one's own bet in favor of intelligence, the ability to decide for the informed, and self-commitment of people.

If we hold a conception of people based on autonomy and freedom, we cannot avoid those people deciding what rights they want to include in the Constitution and how to implement this, and then find the formula that best lends itself to defend them, but without violating democratic principles.

Peru and Ecuador are passing through a period of institutional instability that has affected their governance and their guarantees of democratic consolidation. These countries have not managed to establish a government that meets minimum requirements of effectiveness and legality. In large part, this is because A Soft Rule of Law system was predominant for years in both countries, so that today it is necessary to question the feasibility of creating a democratic state of law and overcoming the prevailing Soft Rule of Law in both countries.

A solid Rule of Law instead of Soft Rule of Law is essential for Peru and Ecuador to add stability and predictability. In addition, it is through legal rules as the place and role of each of the acting subjects in a more developed context (political parties, public authorities, citizens, media, etc.) is delimited.

Título:

‘Gobierno conforme al Derecho’ versus Estado de Legalidad

Sumario:

I. INTRODUCCIÓN. II. LA REGLA DE LEY: UNA REVISIÓN CONCISA. III. REGLA DE LEY Y REGLA DE SOFT LAW. IV. DERECHOS HUMANOS Y LA NORMA DE DERECHO. V. REGLA DE DERECHO Y DEMOCRACIA. VI. ESTADO DE DERECHO Y DEMOCRACIA CONSOLIDADA. VI.1. Estado de Derecho y Reforma del 


\title{
Estado. VII. REGLA DE SOFT LAW EN ECUADOR Y PERÚ. VIII CONCLUSIÓN. REFERENCIAS.
}

\section{Resumen:}

Este artículo efectúa una revisión teórica del término Rule of Law (que puede entenderse como 'Gobierno conforme al Derecho') y el concepto de Soft Rule of Law ('Estado de Legalidad'). Se centra en los derechos humanos como un elemento esencial del gobierno conforme al derecho; además, la interacción entre la democracia y los desafíos que enfrenta el gobierno conforme al derecho en una democracia consolidada. Finalmente, a modo de ejemplo y con propósito descriptivo, presenta una breve reflexión sobre los problemas institucionales actuales de Perú y Ecuador, relevantes para entender las interacciones el Rule of Law y el Soft Rule of Law.

\begin{abstract}
:
This article refers to a theoretical revision of the term Rule of Law and the concept of soft rule of law. It focuses on human rights as an essential element of the Rule of Law, the interaction between democracy and the challenges faced by the Rule of Law in a consolidated democracy. Finally, as an example, it introduces a brief reflection on the current institutional problems of Peru and Ecuador, pertinent for a better understanding of the interactions between the Rule of Law and the Soft Rule of Law.

\section{Palabras clave:}

Estado de derecho; Estado de legalidad; estudios constitucionales comparativos; derechos de propiedad; derecho y economía.

\section{Keywords:}

Rule of law; soft rule of law; comparative constitutional studies; property rights; law and economics.
\end{abstract}


